\title{
Yerel Halkın Kaleiçi Kültür Turizmi Potansiyeline İlişkin Algıları
}

\author{
Local Residents Perception of the Potential of Cultural Tourism in Kaleiçi
}

\begin{abstract}
Altan DEMÍREL*
Öz: Çalışmanın temel amacı, Antalya ili Kaleiçi Bölgesi’nin yerel halk açısından Kültür Turizmi bağlamında tanınırlığını ölçerek, sürdürülebilir turizmin önemli bir basamağı olan kültür turizminin bu bölgede devamlılığını sağlamaktır. Çalışmada frekans ve yüzde analizlerinden ve standart sapma ile ortalama hesaplamalarından faydalanılmıştır. İfadelerin güvenirliği için Cronbach’s Alpha'dan yararlanılmıştır. Gruplar arası farklılıkların ölçülmesi amacıyla parametrik analiz tekniklerinden bağımsız örneklem Ttesti ve tek yönlü ANOVA testinden faydalanılmıştır. Sonuç olarak, Kaleiçi’nde trafik alt yapısı, yerel festivallerin eksikliği ve tanıtım eksikliği göze çarpmaktadır. Ayrıca elde edilen sonuçlar ışığında Kaleiçi ve turizm kavramlarının giderek birbirinden uzaklaştığı görülmektedir.
\end{abstract}

Anahtar sözcükler: Antalya, Kaleiçi, Kültür Turizmi, Kültürel Miras, Sürdürülebilirlik

Abstract: The main purpose of this study was to measure in terms of the local people the recognition of Old Antalya (Kaleiçi) as forming a part of cultural tourism and to ensure the continuity of cultural tourism which is an important step for sustainable tourism within this region. In this study, frequency and percentage analysis and standard deviation and mean calculations were used. Cronbach's Alpha was used for the reliability of the statements. Parametric analysis techniques like one way ANOVA, T-testi were used for measuring the difference between the groups. Results of this research indicate that Kaleiçi's traffic infrastructure, together with the lack of local festivals and the lack of advertising are important. Moreover, it seems to have moved away from the accumulation of Kaleiçi and tourism concepts.

Keywords: Antalya, Kaleiçi, Cultural Tourism, Cultural Heritage, Sustainability

\section{Giriş}

İnsanlar günümüze kadar farklı amaçlar ile seyahat etmişlerdir. Başlangıçta seyahatin amacı insanların yaşamını idame edebilmesi iken, turizm kavramı ile birlikte merak duygusu ön plana çıkmaktadır. Merak duygusu ile birlikte kitle turizmi öncülüğünde birçok turizm türü ortaya çıkmıştır. Kış turizmi, inanç turizmi, kültür turizmi, özel ilgi turizmi, sağlık turizmi, doğa turizmi vb. gibi kavramlar ile turizm türleri çeşitlilik kazanmıştır. Turistlerin istek ve ihtiyaçları farklı1ık göstermektedir. Bazı turistler deniz, kum, güneş, doğa sporları, su sporları gibi etkinliklere önem verirken, bazı turistler ise kültürel ve tarihsel değerleri tecrübe edinmeyi önemsemektedirler. İlgi alanlarını ve ihtiyaçları çoğaltabilmek mümkündür.

Türkiye'de turizm 1980'li yılların başından itibaren Devlet teşvikleri ile birlikte gelişim göstermeye başlamıştır. Turizm Teşvik Kanunu ile birlikte Akdeniz ve Ege kıyılarında yatırımcıları destekleyici politika izlenmesinin ardından turistik tesislerde artış görülmeye başlanmıştır.

\footnotetext{
* Ph.D, Akdeniz Üniversitesi, Sosyal Bilimler Enstitüsü, Turizm İşletmeciliği Ana Bilim Dalı, Antalya. altandemirel@hotmail.com
} 
Turistik tesislerin artmasıyla birlikte ve her şey dâhil sisteminin işlemesi sebebiyle çevre zarar görmüş ve tarihi ve kültürel güzellikler geri planda kalmıştır. Turizm hareketinin yaz aylarına odaklanması verimli bir turizm olayının oluşmasının önünü tıkamaktadır. Kültür turizmi, kış turizmi vb. gibi turizm türlerinin daha etkin olması hem turizmin dört mevsime yayılmasının hem de ekonomik ve sosyal gelişimin kırsal bölgelere yayılmasının önünü açmaktadır.

Her toplum kendi kültürünü ve benliğini ortaya koymaktadır. Ulusların tarihi zenginliği, kültürel çeşitliliğe bağlıdır. Son zamanlarda ise turistleri cezbeden bu kültür farklılıklarıdır. Bu sebeple kültür turizmine olan ilgi giderek artmaktadır. Kültür ve turizm birbiriyle bütün bir olgudur. Özellikle Türkiye coğrafi ve tarihî bakımdan kültürel değerlerinin incelenmesi gereken yerlerden biri konumundadır. Türk kültürü, Orta Asya'ya kadar dayanan tarihi ve günümüze gelene kadar birçok medeniyeti bünyesinde barındırmış olması ile birlikte elimize zengin bir malzeme bırakmıştır. Bu durum da kültürel açıdan dünya üzerinde Türkiye'ye olan ilgi ve alakanın sürekli olmasına sebebiyet vermektedir. Kültür turizmi denilince ilk akla gelen tarihî güzellikler ve doğal güzelliklerdir fakat kutlama şekilleri, eğlence şekilleri ve etkinlikler gibi doğru yaklaşım ve planlamalar, turistlerin bir yerden başka bir yere seyahat etmesi için teşvik edici olabilir. Kültürel etkinliklerin zenginliği ile birlikte destinasyonların imajları olumlu yönde ilerlemesine sebep olmaktadır.

Bu çalışmaya Antalya - Kaleiçi Bölgesi'nde yer alan kültürel varlıkların yerel halk tarafından bilinirliğini ve algısını ölçmek amacıyla yola çıkılmıştır. Bu destinasyonun kültürel aç1dan turizm hareketliliğinin artması için öneriler sunulmuştur. Çalışma üç bölümden oluşmaktadır. İlk bölümde kültür, kültürel miras, sürdürülebilirlik ve kültür turizmi kavramlarının daha iyi kavranabilmesi için literatür taraması yapılmıştır. İkinci bölümde ise Kaleiçi bölgesinde yer alan tarihî ve kültürel yapıların incelemesi yapılmıştır. Literatür taraması yapılan iki bölümde araştırma kaynağ 1 olarak tezler, kitaplar, bilimsel makaleler ve diğer bilimsel kaynaklar kullanılmıştır. Araştırmanın üçüncü ve son bölümünde, yerel halka sorulmak üzere hazırlanmış anket formunun uygulama sonuçları ve bu sonuçların analizlerine ve bulgularına yer verilmiştir. Ayrıca çıkan sonuçlar ışığında çözüm önerileri sunulmuştur ve Kaleiçi bölgesinde gelecek zamanlarda gerçekleşecek turizm faaliyetlerinde nasıl bir yol izlenmesi gerektiği konusunda fikirler belirtilmiştir.

\section{Kültür ve Kültürel Miras Kavramlarının Kapsamı}

Kültür kelimesi etimolojik olarak Latince kökenli “işleme, ekip biçme, tarım; terbiye, hürmet” anlamına gelen 'cultura' kelimesinden gelmektedir. Cultura; özen göstermek, korumak, ikamet etmek, toprağ 1 sürmek, ekip biçmek vd. anlamlara gelen colere mastar fiilinden türetilmiştir (Kabaağaç \& Alova 1995). Latinceden temellenen kültür kelimesi dilimize Fransızca ve Amerikan dilinden gelmiş kabul edilmektedir. Fransızcada kültür kelimesi irfan, Amerikan dilinde ise medeniyet anlamına gelmektedir (Meriç 1986, 15). Ziya Gökalp kültür ve medeniyet kavramlarını ayrı ayrı ele almakta ve kültür yerine hars kelimesini tercih etmektedir. Ziya Gökalp’a göre hars millî, medeniyet ise evrenseldir (Gökalp 1976, 1). Antropolog ve sosyologların çoğu medeniyet kavramını değil, kültür kavramını kullanmaktadırlar. Kimine göre ise bu iki kavram eş anlamlıdır (Meriç 1986, 44).

Kültüre genel bir tanım getiren K. Marx ise, kültürü 'doğanın insanlara sunduklarına karş1lık, insanların ürettiği her şey olarak tanımlamaktadır (Güvenç 2011, 123). Bütün bu tanımlamalar da kültür kavramının genel bir tanımının olmasını zorlaştırmıştır. Ancak Kroeber ve Kluckhohn kültür kavramını 4 başlığa ayırmıştır (Güvenç 2011, 95).

- Bilim Alanında Kültür: Uygarlık/medeniyet anlamına gelmektedir. 
- Beşerî Alanda Kültür: Eğitim ile gelen üründür.

- Estetik Alanda Kültür: Güzel sanatlardır.

- Teknolojik ve Biyolojik Alanda Kültür: Üretim, yetiştirme, ekme ve tarımdır.

Tablo 1 kültür kavramının kullanıldığı alanları açıklamada yardımcı olacaktır.

Tablo 1. Çeşitli Kültür Kavramları ve Anlamları

\begin{tabular}{|l|l|l|l|}
\hline \multicolumn{2}{|c|}{ KAVRAMLAR } & \multicolumn{2}{c|}{ ANLAMLAR } \\
\hline Kullanma Alanlarına göre & Genel & Özel & \multicolumn{1}{c|}{ Nitelikler Görevler } \\
\hline Bilimsel Alanda “Kültür” & Uygarlık & $\begin{array}{l}\text { Çin-Hint Fransız Batı ve İslam } \\
\text { "Kültürü veya Uygarlı̆̆” gibi. }\end{array}$ & $\begin{array}{l}\text { Tarihsel, bütünsel ve } \\
\text { evrensel. }\end{array}$ \\
\hline $\begin{array}{l}\text { Beşerî Alanda-Günlük } \\
\text { Dilde “Kültür” }\end{array}$ & Eğitim & $\begin{array}{l}\text { Genel mesleki ve teknik eğitim; } \\
\text { tıp, hukuk, dil, din, sanat ve fen; } \\
\text { örgün ve yaygın eğitim gibi. }\end{array}$ & $\begin{array}{l}\text { Değerlendirici, } \\
\text { eleştirici, geliştirici, } \\
\text { öğretici ve yay1c1. }\end{array}$ \\
\hline Estetik Alanda “Kültür” & Sanat & $\begin{array}{l}\text { Gotik, Barok, Rönesans ve } \\
\text { modern sanat; resim, müzik ve } \\
\text { gerçekçi sanat gibi. }\end{array}$ & $\begin{array}{l}\text { Eleştirici, yaratıc1, } \\
\text { eğitici, değerlendirici, } \\
\text { güzel ya da } \\
\text { güzelleştirici, estetik }\end{array}$ \\
\hline $\begin{array}{l}\text { Teknolojik ve Biyolojik } \\
\text { Alanda “Kültür” }\end{array}$ & Üretim & $\begin{array}{l}\text { Avcilık, tarım ve endüstri kültürü, } \\
\text { ekin kültürü, mikrop kültürü gibi. }\end{array}$ & $\begin{array}{l}\text { Günlük toplumsal } \\
\text { yaşamı destekleyici, } \\
\text { üretici, deneyci ve } \\
\text { besleyici. }\end{array}$ \\
\hline
\end{tabular}

Kaynak: Lembet 2012, 45.

Kültür mirası ya da kültürel miras, bir toplumun yaşam tarzını ve düşüncesini belirten gelenekgörenek ve nesnelerden meydana gelmektedir. Bu gelenek-görenek ve nesneler belirli bir yaşam tarzını göstermekte, bunun gerçekliğini ve tarihini açılamaktadır. Doğal alanlar, kendine özgü özelliği olan dağlar, göller, tarih öncesi mağaralar, dini merasimlerin yapıldığı mekânlar, antik kalıntılar, bina ve yapılar ve tarihî özelliği olan yerler kültürel miras kapsamında yer almaktadır. Sadece taşınır nesneler olmamakla beraber taşınmaz varlıklar da kültürel miras bakımından önemli bir yere sahiptir (Göğebakan 2014, 49-50). Bu bağlamda somut kültürel miras varlıkları taşınır ve taşınmaz kültür varlıkları olmak üzere ikiye ayrılmaktadır. Taşınmaz kültür varlıkları şehirler, şehir kalıntıları, anıtsal mimariler gibi toplumların hayatında özel ve önemli olayları yaşamış bölgeleri içermektedir. Taşınır kültür varlıkları ise araştırma ve eğitim, etnografya ve açık hava müzeleri bulunmaktadır (Günay 2007, 4-6).

Tablo 2. Kültürel Mirasın Sınıflandırılması

\begin{tabular}{|l|l|l|}
\hline \multicolumn{2}{|c|}{ Söltürel Miras } & \multicolumn{1}{|c|}{ Somut Olmayan Kültürel } \\
\cline { 1 - 2 } Taşınamaz Kültürel Miras & Taşınabilir Kültürel Miras & Miras \\
\hline Mimari Eserler & Resimler & Müzik \\
Anıtlar & Heykeller & Halk Dansları \\
Arkeolojik Sitler & Kütüphane Eserleri & Tiyatro \\
Tarihî Merkezler & Arşivler & Edebiyat \\
Bina Grupları & Takılar Ve Süs Eşyaları & Sözlü Gelenekler \\
Kültürel Manzaralar & Eski Paralar & Törenler, Şölenler \\
Tarihi Parklar, Bahçeler & Günlük Eşyalar & Gelenekler-Görenekler \\
Kanallar, Köprüler & Müzik Aletleri & El Sanatları Geleneği \\
Yel Değirmenleri vb. & Fotoğraflar vb. & Geleneksel Oyunlar vb. \\
\hline
\end{tabular}

Kaynak: Aslan \& Ardemagni 2006 akt. Dönmez \& Yeşilbursa 2014, 427.

17 Ekim-21 Kasım 1972 tarihleri arasında Paris’te toplanan "Birleşmiş Milletler Eğitim, Bilim ve Kültür Örgütü Genel Konferansı”nda 1. Madde’de açıklanan karara göre aşağıda belirtilenler "somut kültürel miras" olarak kabul edilmiştir. 
Anıtlar: Tarihî, bilimsel veya sanatsal bakımdan evrensel öneme sahip olan mimari yapıtlar, resim ve heykel dalındaki başyapıtlar, mağaralar, kitabeler ve arkeolojik özelliği olan yapılar.

Yapı Toplulukları: Mimari yapısı gereği, alan üzerindeki konumu sebebiyle sanat, tarih ve bilim bakımından evrensel bir değeri olan birleşik veya ayrı yapı toplulukları.

Sitler: Tarihsel, estetik, etnik köken açısından evrensel bir öneme sahip olan, insan tarafından ortaya çıkarılmış veya doğa ve insanın ortak ürünü olarak ortaya çıkarılmış eserler ve arkeolojik sit alanları (UNESCO 2018).

Somut olmayan kültürel miras ise; gruplar ve toplulukların bazı durumlarda ise bireylerin, kültürleri olarak ifade ettiği bilgi, uygulama, temsil ve uygulama ve bunlarla ilgili araç ve gereçler olarak belirtilmektedir. Nesilden nesile ulaşan bu miras, toplulukların doğa, tarih ve çevre ile ilişkilerine bağlı olarak yeniden ortaya çıkarılmaktadır ve mirasın günümüze kadar ulaşması sağlanmaktadır. Bu sebeple kültürel çeşitliliğe de katkıda bulunulmaktadır.

UNESCO (2018), Somut Olmayan Kültürel Miras'1 “Toplulukların, grupların ve kimi durumlarda bireylerin, kültürel miraslarının bir parçası olarak tanımladıkları uygulamalar, temsiller, anlatımlar, bilgiler, beceriler ve bunlara ilişkin araçlar, gereçler ve kültürel mekanlar" biçiminde tanımlamıştır. UNESCO'nun 2003 yılında kabul ettiği Somut Olmayan Kültürel Miras Sözleşmesi, somut olmayan kültürel mirasın kapsadığı alanları; somut olmayan kültürel mirasın aktarılmasını sağlayan dil, sözlü gelenek ve anlatımlar, gösteri sanatları, toplumsal uygulamalar, ritüeller ve şölenler, doğa ve evrenle ilgili bilgi ve uygulamalar ve el sanatları geleneği şeklinde belirtmiştir. Sözleşme; bu kapsadığı alanları göz önünde bulundurarak kültürel mirasın araştırılmasını, toparlanmasını, müzeler açılmasını, ders olarak verilmesini, arşiv bölümünün oluşturulmasını, medyada kültür değerlerinin yer almasını, nesiller arası kopuklukları ortadan kaldıracak şekilde verimli bir biçimde değerlendirilmesini öngörmektedir. Ayrıca Somut Olmayan Kültür Mirası Sözleşmesi, yeni neslin bilinçlenmesi gerektiğini, uluslararası devletlerin karşılıklı olarak iş birliği ve yardımlaşma ruhu ile birlikte kültürel mirasın korunması gerektiğini ve buna gerekli önemin verilmesi gerektiğini amaçlamıştır (Kültür ve Turizm Bakanlığı 2013).

Kültürel varlıklar nesillerce aktarıldıkça ilgi çekici, merak uyandırıcı bir hâl almaya başlamıştır. İnsanlar eski uygarlıkların kültürel izlerini görme merakının yanı sıra, başka kültürleri de merak etmeye başlamışlardır. Bu durum da kültürel turizmin gelişmesine olanak sağlamıştır ve kültür, her zaman turizmin önemli bir parçası olmuştur. (Emekli 2006, 16-18). Kültür turizmi kavramı ile 1980'li yılların başında karşılaşılmakta ve Avrupa Birliği'nin kültürel miras ve kimliğini ortaya çıkarmak amacıyla Avrupa Komisyonu tarafından yapılan çalışmalar sırasında buna rastlanılmaktadır (Çulha 2008, 1829).

"Kültür turizmi nedir?” sorusuna cevap vermek kolay değildir. Çünkü farklı sektörler (turizm ve seyahat gibi) bu kavramı konuyla ilgili birçok tanımlama ile açıklamaya çalışmaktadır (McKercher \& du Cros 2002, 3). Dünya Turizm Örgütü (WTO), kültür turizminin iki tanımını yapmaktadır. En dar anlamda kültürel turizm, özellikle kültürel motivasyon için seyahatleri, iş turlarını, kültürel turları, festivaller ve sahne sanatları için turları, anıt ve sit ziyaretlerini, yöresel ziyaretleri ve hac ziyaretlerini içermektedir. Daha kapsamlı şekilde ise tüm bu seyahatler çeşitlilik için insanların ihtiyaçlarını karşılamaya, kültürel seviyelerini artırma eğilimine ve yeni bilgi ve deneyim kazanmaya yöneliktir, diye açıklamaktadır (Pedersen 2002, 8). Tüm bunlar dikkate alındığında kültür turizmi türünün amaçları; yerel mimariyi, tarihî yapıları ve eski eserleri görmek, fuar ve festivallere katılmak, yerel mutfakları deneyimlemek, dinî amaçlı seyahatler gerçekleştirmektir (Bandeoğlu 2015, 158). Turistlerin farklı kültürlere 
karşı geliştirdiği merak duygusu ile gerçekleştirdikleri bu kültür amaçlı seyahatler ve konaklamaları "kültür turizmi” olarak anmak mümkündür (Uygur \& Baykan 2007, 34).

Kültürel çekicilik, kültürel cazibe turizm ürünlerinin temelini oluşturmaktadır. Her bölgenin de kendine özel bir kültürel cazibesi vardır. Bu düşünce ile yola çıkıldığında ise turizmin işlevi sanatsal özellik bakımından estetik temsil, kültürel ve tarihî açıdan sembolik gölge ve bir yere özgü karakter bakımından ise tecrübe olmak üzere 3 başlıkta ele alınmaktadır. (Schweitzer 1999, 121-123). Schweitzer bu üç başlığın önemini üç yönden incelemiştir.

- Değer artırıcı yön: Kültür turizmi, her toplumun kendine özgü kültürel özelliklerini, her zaman geçerli olan kültürel yapı özelliklerine dâhil ederek değerini artırmaktadır.

- Farklılık oluşturucu yön: Kültür turizminin faaliyete geçtiği bölgeler, kendisi gibi kültürel amacı olan diğer bölgelerden farklıdır. Özel bir karaktere sahiptir.

- Rekabeti ortadan kaldırıcı yön: Kültürel yapılar ne kadar farklılaşırsa o kadar farklı turizm alanları yaratılır. Bu farklılıklar da kültürel aktivitelerin olduğu destinasyonlarda rekabet ortamının ortadan kaldırılmasını sağlar. Diğer bir söyleyişle bu kültürel yapılar arasında kıyaslama yapılamaz.

Avrupa Turizm Enstitüsü (ETI), kültür turizminin ortaya çıkaracağı kültürel, toplumsal ve ekonomik yararları ve olumsuzlukları açıklamaktadır. Bir destinasyona özgü kültürel ve doğal mirasın, kültürel turizm kaynağı olarak değerlendirilmesi, kültür turizmine dâhil olanların satın alma güçlerinin yüksekliği sebebiyle, bölge için yüksek değer katması, talepte çeşitlilik yaratarak kaynakların aşırı kullanılmaması, yeni istihdamlar yaratılması ve mevcut talebi geliştirilerek turizm faaliyetlerine katkıda bulunulması turizme yarar sağlarken; kaynak yönetimine itina ile yaklaşılmazsa destinasyon için olumsuzluklar yaratılması, kitlelerin destinasyon içinde kalabalık oluşturması, turist isteklerine göre hareket edilip bölge özelliklerinin yok olması ve tarihsel yapıların düzenlemesi sırasında gerçeğe uygun bir şekilde düzenlenmemesi ortaya çıkabilecek olumsuzluklar olarak belirtilmektedir (Fuchs et al. 1995, 26). Bu sebeplerden dolayı, kültürel miras üzerinde yapılan çalışma ve planlar giderek artan bir önem kazanmaktadır. Kültürel varlıklar özellikle somut kültürel miras varlıkları, kültürel mirasın oluşumundaki temel unsurlardır ve bu unsurların yasalar ile korunması gerekmektedir (Doğaner 2013, 13).

Kültür kavramının sadece geçmiş ile sınırlandırılmadığı ve bugünü de kapsamına aldığı düşünüldüğünde, kültür turizmini tarihsel ve güncel açıdan iki bölüme ayırmak olasıdır.

Güncel kültür turizmi: Burada etkinlikler ön plana çıkmaktadır. Yöresel, küçük bölgesel, önemli bölgesel, ulusal ve uluslararası büyük etkinlikler olmak üzere beş ana başlıkta toplanmaktadır.

1. Yöresel Etkinlikler: Yöresel festivaller, tiyatro gösterileri ve resim sergileri.

2. Küçük Bölgesel Etkinlikler: Fuar ve sergiler.

3. Önemli Bölgesel Etkinlikler: Festivaller (İstanbul Müzik Festivali gibi).

4. Ulusal Etkinlikler: Karnavallar ve Festivaller (Rio Karnavalı ve Cannes Film Festivali gibi).

5. Uluslararası Etkinlikler: Olimpiyatlar ve büyük turnuvalar (Dünya Kupası, Olimpiyat Oyunlar1 gibi).

Tarihsel kültür turizmi: Milli sınırlar içerisinde bulunan kültür mirasının bir organizasyon ile reklam ve tanıtımının yapılması esasına dayanmaktadır. Bu durum da "tarihi kültürel mirasın sahiplenilmesi” olgusunu desteklemektedir. Tarihî kültür turizmi, toplumun kültürel mirasına sahip çıkması doğrultusunda, yabancı turistlerin ilgisini çekmekte doğru orantılı bir ivme 
göstermektedir (Khalilova 2008, 37).

Kültür turizmine Türkiye açısından bakmak gerekirse; Türkiye, Avrupa ile Asya'yı birleştiren bir köprü niteliğinden dolayı dünya kültüründe de önemli bir yere sahiptir (Çakır 1999, 46). Türkiye konumu açısından tarih boyunca birçok uygarlığa ev sahipliği yapmış ve birçok farklı kültürlerin merkezi hâline gelmiştir. Hititler, Galatlar, Urartular, Lidyalılar, Likyalılar, Helenler, İyonlular, Roma, Selçuk ve Osmanlı gibi birçok uygarlık bu ülkede yaşamıştır (Genim 2002, 205-210). Tüm bu uygarlıkların günümüze kadar ulaşan kültürel varlıkları oldukça ilgi çekmektedir. 1946 yılında 2. Dünya Savaşı'ndan sonra kurulmuş olan bir kurum olan UNESCO, üye ülkelerin imzaladığı sözleşme ile bu varlıkların korunması ve tanıtılmasında önemli bir rol oynamaktadır. Kültür Varlıkları ve Müzeler Genel Müdürlügü’nün gözetiminde yürütülen çalışmalar neticesinde bugüne kadar 17 adet varlığımızın alınması sağlanmıştır (Kültür Varlıkları ve Müzeler Genel Müdürlüğü 2018).

Kültürel olarak;

- İstanbul'un Tarihi Alanları (1985)

- Divriği Ulu Camii ve Darüşşifas1- Sivas (1985)

- Hattuşa (Boğazköy) Hitit Başkenti (Çorum) (1986)

- Nemrut Dağı (Adıyaman-Kahta) (1987)

- Ksanthos-Letoon (Antalya-Muğla) (1988)

- Safranbolu Şehri- Karabük (1994)

- Troya Antik Kenti- Çanakkale (1998)

- Edirne Selimiye Camii ve Külliyesi- Edirne (2011)

- Çatalhöyük Neolitik Kenti-Konya (2012)

- Bergama Çok Katmanlı Kültürel Peysaj Alanı-İzmir (2014)

- Bursa ve Cumalıkızık: Osmanlı İmparatorluğunu Doğuşu- Bursa (2014

- Diyarbakır Kalesi ve Hevsel Bahçeleri (2015)

- Efes-İzmir (2015)

- Ani Arkeolojik Alan1-Kars (2016)

- Afrodisias-Aydin (2017)

Hem kültürel hem de doğal miras olarak listeye alınanlar ise;

- Göreme Milli Park1 ve Kapadokya- Nevşehir (1985)

- Pamukkale-Hierapolis- Denizli (1988)

Bunun yanı sıra doğal ve kültürel olmak üzere 69 adet varlık da Dünya Miras Geçici Listesi’nde yer almaktadır (Kültür Varlıkları ve Müzeler Genel Müdürlüğü, 2018).

\section{Sürdürülebilirlik ve Turizm}

1960'lı yıllardan beri uzmanlar, doğadaki çevre tahribatı konularına ilgi çekmekte ve eleştirilerde bulunmaktadırlar. Fakat bu süreçte eşik oluşturan, 70'li y1llarda "sürdürülebilirlik" kavramının gündeme gelişidir. Sürdürülebilirlik kavramı, ilk olarak 1972 yılında Stockholm'de düzenlenen Dünya Çevre Konferansı Raporu'nda yer alan "eko-gelişme" kavramı çerçevesindeki tartışmalara bağlı olarak gelişmiştir. 1972 yılında ise Roma Kulübü "Büyümenin Sınırları" başlıklı bir çalışma yayımlamıştır. Bu çalışma, büyüme ve kaynaklar arasındaki ilişkiye dikkat çekmektedir. "Sıfır Büyüme Raporu" olarak da bilinen bu rapor ülkeler arasında gelişme, sanayileşme ve çevre arasındaki sorgulamayı tetiklemiş̧ir (Küçükaslan 2007, 46). Sürdürülebilirlik kavramı 1987 yılında Brundtland Raporu olarak da bilinen "Birleşmişs Milletler Ortak Geleceğimiz Raporunda" ifade edilmiştir ve daha sonra 1992 Rio Dünya Zirvesi'nde çevre kavramı ele alınmış ve ülkelerin bu konuda yasal düzenlemelere gitmesi gerektiği belirtilmiştir (Gönel 
2002, 74). 1987 Brundtland Raporu’na göre sürdürülebilirlik için bütüncül planlama ve stratejik geliştirme, temel ekolojik süreçleri koruma, insan mirasını ve bio-farklılığı koruma, verimliliğin uzun bir döneme yayılmasına izin veren büyüme modelleri, ekonomik büyüme ile doğal kaynaklar arasında denge, ülkeler arası hakça oluş ile olanaklar arasındaki denge, gibi ilkeler belirlemişlerdir (Himmetoğlu 1996). 1992 Rio öncesindeki bir gelişme yine 1992'de gerçekleşen Heidelberg Buluşması'dır. Altmıştan fazla ünlü bilim adamının oluşturduğu bir ekip çevre hareketlerine karşıt bir görüş belirtmiş ve yapılan çalışmaların sözde bilimsel olduğunu ayrıca ülkelerin giderek ekonomik bağımsızlıklarını tehdit ettiği görüşünü savunmuştur. Rio Zirvesi'nden 5 yıl sonra gerçekleşen Kyoto Protokolü ise sürdürülebilirlik kavramını, "İklim Değişimleri ve Etkileri” başlığı altında gündeme getirmiştir. Buna bağlı olarak sürdürülebilirlik kavramının sadece küresel bir ortaklık düşüncesi ile gerçekleşeceğini savunarak, bu ortaklığa yön verebilmek için Birleşmiş Milletler Sürdürülebilir Kalkınma Komisyonu'nun temeli atılmıştır (Küçükaslan 2007, 46).

İngilizcede "sustainability" olarak ifade edilen kavram dilimize sürdürülebilirlik şeklinde dâhil olmuştur. Kelimenin anlamına bakılacak olursa beslemek ve devam ettirmek anlamı ortaya çıkmaktadır. Fakat işlevsel olarak bakılacak olursa "sürdürülebilirlik" kavramı birçok tanımla ifade edilmektedir (Küçükaslan 2007). Sürdürülebilirlik; günümüz ihtiyaçlarını karşılarken, elde bulunan doğal kaynakları muhafaza etmek ve gelecek kuşaklara iyi bir ortam bırakmak için yapılan çalışmalardır (Kuter \& Ünal 2013, 147). Bramwell ve Lane $(2000,84)$ sürdürülebilirlik kavramının, yalnızca çevre veya yeşil kavramlarıyla beraber ele alınmaması, huzurun ve sosyal ihtiyaçların nasıl elde edileceği ile ekonomik ve çevresel şartların yarattığı kısıtlamalar dâhilinde nasıl bir çözüm bulunması gerektiği de düşünülmelidir şeklinde tanımlamıştır. Uzmanlar tarafından sürdürebilirlik kavramının farklı tanımları olmasıyla beraber çok geniş bir anlamı kapsadığ 1 ve tüm toplum bireylerini etkilediği görülmektedir. Ortak çıkarılan nokta ise sürdürülebilirlik kavramının 3 boyutu olduğudur. Çevresel boyutu daha çok göz önünde olsa da ekonomik ve sosyal boyutunu da bir bütün olarak görmek gerekmektedir.

Turizm, zengin kaynaklara sahip birçok bölge için ekonomik açıdan ve iş istihdamı sağlamada önemli bir konumdadır. 1970 ve 1980 yılları arasında çevresel etkenler de göz önünde tutulmaya başlanmıştır (Pfoor 2001, 68). Fakat bu ekonomik durum, çevresel etkilerin arka plana atılmasına sebep olmaktadır. Ayrıca turizm kitle tüketimi yüzünden olumsuz etkilenmektedir. Kitle turizminin sezonluk olması, talep yüksek olduğu için ve yerel kaynaklara aşırı yüklenildiği için turizmi olumsuz etkilerini artırmaktadır (Kozak \& Martin 2012, 191). Bu bağlamda bireysel olarak veya küçük gruplar olarak yapılan turizm aktiviteleri de bir destinasyon içerisinde kitlelere ulaşmaktadır. Yalnız turizmdeki çevresel olumsuzlukları sadece turist sayısına bağlamak yanlıştır. Bu durumdan daha önemli olarak destinasyon içindeki sanayileşme, işin nasıl yapıldığı, teknolojik ürünler ve bu ürünlerle birlikte diğer ürünlerin yapısı da turizmi olumsuz etkilemektedir (Erdoğan 2003, 99-104).

Doğal ve kültürel varlıkların sürdürülebilirliği, turizmin de devamını ve sürdürülebilirliğini sağlayacaktır. Ancak bu devamlılık ve sürdürülebilirlik ayrıca doğal ve kültürel varlıkları daha verimli bir şekilde kullanılabilmek için bu varlıkların korunmasının sağlanması gerekmektedir (Kozak 2013, 2-3). Bunun için de özel sektör, çevreci kuruluşlar ve yerel yönetimler turizm ile ilgili planlamalarda belirli bir uyum göstermelidirler. Öyle ki bu planlamaların uygulanabilirliği için birlikte hareket etmekle yükümlüdürler (Ahipaşaoğlu \& Çeltek 2006, 105-106).

\section{Antalya'nın Tarihi ve Tarihî Yapıları}

Antalya şehrinin bulunduğu bölgeye antikçağda Pamphylia, batı kesimine ise Lykia adı ve- 
rilirdi. MÖ VIII. yüzyıldan sonra Ege üzerinden bu bölgeye Aiolialı göçenler gelerek Side ve Aspendos gibi yerleşim yerlerini kurmuşlardır. MÖ II. yüzyılın ortalarında II. Attalos şu anki şehir merkezinin bulunduğu bölgede bir şehir kurmuştur. İlk olarak kral kendi adına izafeten kente Attaleia adını vermiş, kent daha sonra Adalya daha sonra da Antalya adını almıştır.

Antalya kentinin yaklaşık 30 km kuzeyinde yer alan Karain Mağarası ile kentin tarihi günümüzden 500 bin y1l öncesine kadar uzanmaktadır (Sagona \& Zimansky 2015, 14) İlk yerleşim gördüğü andan itibaren kent, kesintisiz olarak iskân görmeye devam etmiştir. Bölge, antikçağın Lykia, Pisidia ve Kilikia bölgeleri ile çevrelenmiş bölgede ve dolayısıyla kentte Persler, Büyük İskender ve onun ardılları Ptolemaioslar, Seleukoslar ve Pergamon krallıkları hüküm sürmüştür.

Roma Dönemi'nde ise donanma üssü olarak kullanılan kent ticaret yollarının da denize bağlanması açısından bir liman kenti kimliğine sahip olmuştur. Bu liman kenti olması özelliği Selçuklu ve Osmanlı egemenliğinde de devam etmiştir. 15. yüzyılda Osmanlı İmparatorluğu zamanında kentin surları, Selçuklu döneminden kalma birbirinden ayrılmış iç yapısı özelliğini kaybetmiştir. Günümüzde Kaleiçi ile birlikte Haşim İşcan ve Balbey mahalleleri bu dönemde meydana gelmiştir. Hala bu üç bölgeden başka kentin organik dokusunu koruyan başka bir bölge bulunmamaktadır (Kepenek et al. 2015).

Antalya, Osmanlı hâkimiyeti altına girdikten sonra Teke Sancağı adıyla anılmaya başlanmıştır. Konya ve Karaman eyaletlerine bağlı bir şekilde yönetilmiştir (Özdemir 1992, 142). Birinci Dünya Savaşı'ndan önce Teke Sancağı, Konya merkezinden ayrılarak bağımsız bir sancak hâline geldi. O dönemde İtalyanlar şehri işgali altında tutarken aynı zamanda Yunan işgalinin olduğu bölgelerden Antalya’ya göç edenlere okullar ve yollar açarak kendilerini Türk dostu olarak göstermeye çalışıyorlardı. Fakat şehir çok geçmeden boşaltılmıştır. 9 Temmuz 1921 tarihinde İtalyanlar geri çekilince Antalya, Anadolu Hükümeti'ne bağlandı ve Cumhuriyet'in ilanından sonra şehir bugünkü görünümüne kavuşup ve Antalya adını almıştır. (Antalya Belediyesi 2016).

Antalya bölgesinin tarihine bakıldığında kentin, Kaleiçi Bölgesi'nin çevresinde büyüyüp geliştiği görülmektedir. Yat limanı sayesinde de ticarete dâhil olmuştur. Kaleiçi; Selçuk, Tuzcular, Barbaros ve Kılınçarslan olmak üzere dört mahalleden oluşmaktadır. Antalya'nın simge yapısından biri olan Yivli Minare ve külliyesi Kaleiçi'nin kuzey tarafındaki Selçuk Mahallesi'ndedir. 19. yüzyılda Selçuk Mahallesi ve Tuzcular Mahallesi çoğunlukla Müslüman halkın bulunduğu bölgedir. Kaleiçi'nin güney ve doğu bölümü ise Rum halkının bulunduğu, 19. Yüzyıla kadar bu bölgenin Rum Mahallesi olarak bilindiği kesim olarak bilinmektedir. Günümüzde Kılınçarslan ve Barbaros mahalleleri olarak bilinen bu bölgede Yeni Kapı Rum Kilisesi ve Aya Yorgi Kilisesi bulunmaktadır (Avcı 2015, 117). Kaleiçi'nin kültürel varlıkları, Tablo 3’te kategoriler halinde belirtilmiştir.

Tablo 3. Kaleiçi'nin Kültürel Varlıkları

\begin{tabular}{|llll|}
\hline Tarihi Yapılar & Dini Yapılar & Müzeler & Eğitim Amaçlı Yapılar \\
-Kale Kapısı & -Kesik Minare Camii & -Atatürk Evi ve Müzesi & -İmaret Medresesi \\
-Saat Kulesi & -Alaaddin Camii & -Suna-İnan Kıraç & -Atabey Armağan \\
-Yivli Minare & -Nigâr Hatun Türbesi & Kaleiçi Müzesi & Medresesi \\
-Kale Kapısı Hanları & -Yivli Minare Camii & -Antalya Oyuncak & -Karatay Medresesi - \\
-Kırk Merdiven & (Alaaddin Camii) & Müzesi & Dumlupınar Ortaokulu \\
-Uzun Çarşı Surları ve & -Tekeli Mehmet Paşa & -Suna-İnan Kıraç & İdari Binalar \\
Kitabeleri & Camii & Kaleiçi Müzesi & -Antalya Lisesi İdari \\
-Kaleiçi’nin & -Karamolla Mescidi - & -Demirciler Çarşısı Ve & Binaları \\
Geleneksel Evleri & İskele Mescidi & Soba Müzesi & -Büyükşehir Belediye \\
\hline
\end{tabular}




\begin{tabular}{|c|c|c|c|}
\hline -Hıdırlık Kulesi & -Ahi Yusuf Camii & Hamamlar & Binas1 \\
\hline -Yivli Minare & -Zincirkıran Mehmet & -Nazır Hamamı & -Öğretmenler Lokali \\
\hline $\begin{array}{l}\text { Külliyesi } \\
\text {-Antik Tiyatro }\end{array}$ & Bey Türbesi & -Cumhuriyet Hamamı & Anitlar Heykeller \\
\hline -Sur Duvarları & -Ahi Kızı Mescidi & -Rum Millet Hamamı & -Attalos’un Heykeli \\
\hline -Mermerli Plaj1 & -Muratpaşa Camii & (Gâvur Hamamı) & -Ulusal Yükseliş Anıtı \\
\hline -Yat Limanı & -Ahi Kızı Türbesi & -Pazar Hamamı & Rekreasyon Alanları \\
\hline -Hadrianus Kapısı (Üç & -Balbey Camii & -Balık Pazar'ı Hamamı & -Karaalioğlu Parkı \\
\hline Kapılar) & $\begin{array}{l}\text {-Aziz Alypios } \\
\text { (Yenikap1 Rum) } \\
\text { Kilisesi }\end{array}$ & -Yivli Minare Hamamı & $\begin{array}{l}\text {-Atatürk Caddesi } \\
\text {-Hesapçı Sokak }\end{array}$ \\
\hline
\end{tabular}

\section{Araştırmanın Yöntemi}

Antalya - Kaleiçi Bölgesi tarihten günümüze kadar birçok uygarlığa tanıklık etmiş ve kültürel değerler açısından zengin bir yer konumundadır. Doğal güzellikleri ve tarihî dokusu ile birlikte sadece Antalya'nın değil aynı zamanda Türkiye'nin de önde gelen cazibe merkezlerinden biridir. Bu çalışma Antalya ve Kaleiçi Bölgesi'nin tanıtımının çeşitlendirilmesi, kültürel bir cazibe merkezi olarak değerlendirmesi, ayrıca bu turistik ve tarihî bölge için bir bilinç oluşturulması açısından önem taşımaktadır. Bu sebeple bu cazibe merkezinin bilinirliğini artırmak için bu çalışmada, Kaleiçi destinasyonunun kültürel yapısı, doğal çekicilikleri ve tarihî dokusu incelendikten sonra, bölgenin bilinirliğini anlamak ve farkında olunmayan güzelliklerinin ortaya çıkarılmasını sağlamak amaçlanmıştır.

Çalışmanın analiz bölümünde veri toplama aracı olarak anket tekniği kullanılmıştır. Antalya'da yaşayan yerel halkın demografik özellikleri, ziyaret amaçları, destinasyonda yer alan tarihî yapıların bilinirliği analiz edilmiştir. Kaleiçi Bölgesi’nin kültürel açıdan sahip olduğu potansiyelin, bu potansiyelden ne kadar yararlanıldığı ve Kaleiçi Bölgesi'ne ilişkin algının ne boyutta olduğunun ölçülmesi amaçlanmaktadır. Ayrıca elde edilen bulgular ile Kaleiçi Bölgesi'nde ortaya çıabilecek olumsuzlukları ele almak için ve mevcut potansiyelinden nasıl daha verimli bir şekilde yararlanılabileceği sonucuna ulaşmak için mevcut durum ortaya konulmuştur.

Çalışma, Antalya'da yaşayan yerel halk üzerinde yapılmıştır. Yapılan bu çalışma da bazı varsayım ve sınırlılıkları ortaya çıkarmıştır. Araştırmada Antalya'da yaşayan halkın Kaleiçi Bölgesi'ni değerlendirebilecek donanıma sahip oldukları ve anket aşamasında cevaplanan soruların objektif olduğu varsayılmıştır. Araştırma, veri toplama aşamasında Antalya'da ikamet eden halk ile sınırlandırılmıştır. Ayrıca araştırmanın sonuçları sadece Antalya - Kaleiçi Bölgesi’ne yöneliktir ve başka destinasyonlar üzerinde genelleme yapılamamaktadır. Son olarak çalışma, soru formunda kullanılan ölçeklerde bulunan ifadeler ile sınırlandırılmıştır.

Antalya Kaleiçi Bölgesi’ndeki algının ve bilinirliğin artmasına katkı sağlanması amacıyla detaylı bir literatür taraması yapıldıktan sonra Üsküdar'ın (2012) çalışmasında kullanmış olduğu soru formu temel alınarak çalışmanın amacına yönelik bir soru formu geliştirilmiştir.

Soru formunda aralıklı ve nominal düzeyde sorular bulunmaktadır. Nominal ölçek düzeyinde hazırlanan sorular; yerel halkın yaş, cinsiyet, medeni hâl, eğitim düzeyi ve ortalama aylık geliri gibi demografik özelliklere yanıt aramaktadır. Katılımcılara, Kaleiçi’nin daha önce kaç kere ziyaret edildiği, bu ziyaretteki amaç ve ziyaret edilen bölgenin ne derecede önemli olduğu, ziyaret edilen veya edilecek mekânlar, ziyaret sırasında kiminle gezildiği gibi sorular yöneltilmiştir. Katılımcıların seyahat tecrübelerine yönelik 14 madde (1-Çok Kötü, 2-Kötü, 3-Orta, 4-İyi ve 5Çok iyi) sorulmuştur, 12. soru ise Kaleiçi'nde bulunan yapıların bilinirliğini ölçmek amacıyla (bilmiyorum, biliyorum ama gezmedim, biliyorum ve gezdim) sorulmuştur. Son olarak kültürel bir bölge olarak Kaleiçi algısını ortaya koymak için hazırlanan 9 ifade (1- Kesinlikle Katıl- 
miyorum, 2- Katılmıyorum, 3- Kararsızım 4- Katılıyorum ve 5- Kesinlikle Kat1lıyorum) yer almaktadır.

\section{Araştırmanın Evreni ve Örneklemi}

Araştırmanın evrenini Antalya'da ikamet eden yerel halk oluşturmaktadır. Türkiye İstatistik Kurumu (TÜİK) raporlarına göre bunların sayısı Antalya'da 2.328.555 olarak belirtilmektedir. Antalya merkez belediyelerine bağlı ise 1.217.314 kişi bulunmaktadır (TÜíK 2016).

Örneklem büyüklüğü belirli bir güvenilirlik aralığı temel alınarak hesaplanmıştır. Evren varyansının tam olarak bilinemediği durumlarda araştırma için bir ön örneklemin belirlenmesi gerekmektedir. Belirlenmiş bu ön örneklemden evren varyansının yaklaşık değerinin hesaplanması ve böylelikle araştırma için yeterli örneklem büyüklüğünün hesaplanması daha doğru olacaktır (Delice 2010, 166). Bu bağlamda araştırmada örneklem büyüklügünün belirlenmesi amacıyla evren varyansı olarak Antalya'nın merkez nüfusu temel alınmış ve büyük örneklemler için örneklem büyüklükleri tablosundan faydalanılmıştır. Örneklem büyüklükleri tablosu göz önünde bulundurulduğunda 0.05 örneklem hatası ile 1.217 .314 kişiden oluşan evreni temsil etme gücüne sahip örneklem büyüklügünün 384 olduğu görülmektedir. Ancak zaman ve mekân sıkıntıları nedeniyle 300 katılımcıya ulaşılmıştır. İlgili alanyazın incelendiğinde, araştırmanın gerçekleştirileceği örneklem büyüklüğünün, normal dağılımın bulunmadığı durumlarda araştırmada kullanılan ölçeği oluşturan değişken sayısının 10 katı; normal dağılımın bulunduğu durumlarda 5 katı olması gerektiğini ileri süren çalışmalar (Jayaram et al. 2004, 4388; Yiğit et al. 2008, 43) bulunmaktadır. Dolayısıyla araştırmanın gerçekleştirildiği örneklem büyüklüğünün yeterli olduğunu söylemek mümkündür.

\section{Verilerin Toplanması}

Anket formu olasılığa dayalı olmayan örnekleme yöntemleri içerisinde yer alan, kolayda örnekleme yöntemi kullanılmıştır. Araştırmanın örneklemi 30 Eylül 2016 - 1 Ocak 2017 tarihleri arasında yerel halktan seçilerek 93 anket elden, 232 anket ise internet üzerinden toplanmış olup 325 kişiye ulaşılmıştır. Elde edilen anketlerden 25 'i, veri ve anlamlılık yeterliliği olmadığı tespit edilerek değerlendirme kapsamına alınmamıştır. Geri kalan 300 anket ise değerlendirme dâhilinde tutulmuştur.

\section{Verilerin Analizi}

Araştırmada katılımcıların demografik özelliklerini belirlemek için frekans, standart sapma, yüzde ve ortalama analizlerinden yararlanılmıştır. Çalışmada kullanılan ölçeklerin güvenirliliğini ölçmek için Cronbach's Alpha'dan faydalanılmıştır. Katılımcıların Kaleiçi Bölgesi'nin ziyaret tecrübelerine göre değerlendirdikleri sorudaki ifadelerin güvenirliliği $\alpha=0,871$, Kaleiçi Bölgesi’nin kültürel algılarının ölçüldüğü ifadelerin güvenirliliği $\alpha=0,930$ olarak bulunmuştur. Verilerin dağılımı incelendiğinde normal dağılım gösterip göstermediğini belirlemek amacı ile çarpıklık (skewness) ve basıklık (kurtosis) değerleri incelenmiştir. Bu değerlerin -2 ve +2 aralığında olduğu görülmüştür ve bu dağılımın normal bir dağılım olduğu kabul görülmektedir. $\mathrm{Bu}$ sebeple parametrik analiz tekniklerinin uygulanmasında bir sakınca bulunmamaktadır. Belirli gruplar arasında farklılık bulunup bulunmadığını incelemek amacıyla Parametrik analiz tekniklerinden “Bağımsız örneklem T-testi ve tek yönlü ANOVA Testi” kullanılmıştır. 


\section{Bulgular ve Değerlendirme}

\section{Katılımcıların Demografik Özellikleri, Ziyaret Sayısı, Ziyaret Amacı ve Önem Sıralaması}

Tablo 4. Yerel Halkın Demografik Özellikleri, Ziyaret Sayısı, Ziyaret Amacı ve Önem Sıralaması

\begin{tabular}{|c|c|c|c|}
\hline & & $\mathbf{n}$ & $\%$ \\
\hline \multirow{5}{*}{ Yaş } & 18 yaş ve altı & 5 & 1,7 \\
\hline & 19-29 yaş arası & 187 & 62,3 \\
\hline & 30-39 yaş arası & 70 & 23,3 \\
\hline & 40-49 yaş arası & 26 & 8,7 \\
\hline & 50 yaş ve üzeri & 12 & 4 \\
\hline \multirow{2}{*}{ Cinsiyet } & Kadın & 157 & 52,3 \\
\hline & Erkek & 143 & 47,7 \\
\hline \multirow{2}{*}{ Medeni Durum } & Bekâr & 190 & 63,3 \\
\hline & Evli & 110 & 36,7 \\
\hline \multirow{6}{*}{ Eğitim Durumu } & İlköğretim & 3 & 1 \\
\hline & Ortaöğretim & 2 & 0,7 \\
\hline & Lise & 38 & 12,7 \\
\hline & Ön lisans & 73 & 24,3 \\
\hline & Lisans & 131 & 43,7 \\
\hline & Lisansüstü & 53 & 17,7 \\
\hline \multirow{5}{*}{ Aylık Gelir } & $0-1000 \mathrm{TL}$ & 67 & 22,3 \\
\hline & 1001-2000 TL & 129 & 40 \\
\hline & 2001-3000 TL & 51 & 17 \\
\hline & 3001-4000 TL & 40 & 13,3 \\
\hline & 4001 TL ve üzeri & 22 & 7,3 \\
\hline \multirow{3}{*}{$\begin{array}{l}\text { Katılımcıların } \\
\text { Önem Sıralaması }\end{array}$} & 1. Kültür & 104 & 34,7 \\
\hline & 2. $\quad$ Tarih & 117 & 39 \\
\hline & 3. Eğlence & 126 & 42 \\
\hline \multirow{7}{*}{$\begin{array}{l}\text { Ziyaret Edilen } \\
\text { Mekân ve Aktiviteler }\end{array}$} & Tarihi mekanlar & 235 & 78,3 \\
\hline & Müzik-dans etkinlikleri & 155 & 51,7 \\
\hline & Müzeler & 135 & 45,0 \\
\hline & Camiiler/kiliseler & 118 & 39,3 \\
\hline & Festivaller & 93 & 31,0 \\
\hline & Sanat galerileri & 75 & 25,0 \\
\hline & Diğer eğlence aktiviteleri & 10 & 3,3 \\
\hline \multirow{3}{*}{ Ziyaret Şekli } & Arkadaşlarımla birlikte & 250 & 83,3 \\
\hline & Aile ile birlikte & 133 & 44,3 \\
\hline & Bireysel & 113 & 37,7 \\
\hline
\end{tabular}

Tablo 4. incelendiğinde, katılımcıların yaşlarının \%62,3'ünün 19-29 yaş aralığında olduğu, cinsiyetlerinin \%52,3'ünün kadın, \%47,7'sinin erkek olduğu, medeni durumunun \%63,3'ünün bekâr, eğitim durumunun \%43,7'sinin lisans mezunu ve aylık gelirinin ise \%40'ının 1001-2000 TL aralığında olduğu görülmektedir. Katılımcılara verilen ve turizm özellikleri olarak tanımlanan "kültür, hizmet, ticaret, eğlence ve tarih" kavramlarının, önem sırasına göre ilk üç sıraya konulması istenmiştir. Bu soruya ait bulgulara göre birinci önem derecesine sahip olan kavram \%34,7 ile kültür kavramı, ikinci önem derecesine sahip kavram ise \%39 ile tarih kavramı ve üçüncü önem derecesine sahip olan kavram ise \%42 ile eğlence kavramı olduğu görülmektedir. Hizmet ve ticaret kavramlarının katılımcıların verdiği yanıtlara göre diğer üç kavrama göre daha az oranda önem derecesine sahip olduğunu söylemek mümkündür. Birden çok seçeneğe cevap verilen yerel halkın katıldığı aktiviteler ve ziyaret ettiği mekânlar ile ilgili soruya ilişkin bulgularda ise, \%78,3 ile tarihî mekânlar ve \%51,7 ile müzik-dans etkinlikleri seçenekleri en 
yüksek orana sahiptir. En düşük orana ise \%3,3 ile diğer eğlence aktiviteleri seçeneği sahiptir. Ziyaret şekli ile ilgili verilen cevaplar incelendiğinde arkadaşlarımla birlikte seçeneği \% 83,3 ile en yüksek orana sahip olurken \%37,7 oranla bireysel seçeneği en düşük orana sahip olmuştur.

\section{Yerel Halkın Tecrübelerine Göre Kaleiçi Destinasyonunun Değerlendirme Bulguları}

Katılımcılara Kaleiçi deneyimleri ile ilgili 14 kriter belirlenmiştir ve katılımcılardan bu kriterlere çok iyi ve çok kötü arasında bir cevap verilmesi istenmiştir. Katılımcıların Kaleiçi ile ilgili edindiği deneyimlere ait bulgular Tablo 8'de belirtilmiştir.

Manzara ve doğal çekicilikler incelendiğinde katılımcıların \%86 oranında iyi buldukları görülmekte ve yüzdelik dilime bakıldığında en yüksek orana sahip olan kriter, manzara/doğal çekicilikler olduğu görülmektedir. Tarihî çekicilikler incelendiğinde \%81,7 oranında iyi, kültürel çekicilikler \% 75,3 oranında iyi, eğlence ve gece hayatı $\% 69,7$ oranında iyi, yerel festivallerin imkânı \%29,7 oranında iyi, \%37,7 oranında kötü, kültürel miras \%70,3 oranında iyi buldukları görülmektedir. Trafik altyapısı \%17 oranında iyi, \%56 oranında kötü olması sebebiyle "en düşük iyi” oranına sahiptir. Ayrıca yerel festivallerin imkânı \%29,7 ile iyi, \%37,7 ile kötü oranda olduğu görülmektedir.

Tablo 5. Yerel Halkın Tecrübelerine Göre Kaleiçi Değerlendirme Ortalamaları

\begin{tabular}{|l|c|c|}
\hline & Aritmetik Ortalama & Standart Sapma \\
\hline Manzara/Doğal çekicilikler & 4,22 & 0,7394 \\
\hline Tarihi çekicilikler & 4,13 & 0,7702 \\
\hline Kültürel çekicilikler & 3,96 & 0,8471 \\
\hline Kültürel miras & 3,89 & 0,8368 \\
\hline Eğlence ve gece hayatı & 3,82 & 0,9365 \\
\hline Turistik çekiciliklerin çeşitliliği & 3,54 & 0,9686 \\
\hline Yerel halkın konukseverliği & 3,38 & 0,9623 \\
\hline Konaklama tesislerinin kalitesi & 3,37 & 0,8429 \\
\hline Yiyecek içecek hizmetleri & 3,32 & 0,9676 \\
\hline Temizlik ve hijyen & 3,13 & 0,8947 \\
\hline Alışveriş imkânları & 3,13 & 0,9791 \\
\hline Can ve mal güvenliği & 3,01 & 0,9391 \\
\hline Yerel festivallerin imkânı & 2,92 & 1,0346 \\
\hline Trafik altyapısı & 2,41 & 1,1072 \\
\hline
\end{tabular}

Katılımcıların tecrübelerine göre Kaleiçi Bölgesi'ni değerlendirmelerinin ortalamaları Tablo 5 'te belirtilmiştir. Yukarıdaki tabloya göre manzara ve doğal çekicilikler 4,22, tarihî çekicilikler 4,13, kültürel çekicilikler 3,96 ve kültürel miras 3,89 ortalama ile katılımcıların bu deneyimlere büyük oranda katıldıkları görülmektedir. Bununla beraber; eğlence ve gece hayatı 3,82 , turistik çekiciliklerin çeşitliliği 3,54, yerel halkın konukseverliği 3,38, konaklama tesislerinin kalitesi 3,37, yiyecek içecek hizmetleri 3,32, temizlik ve hijyen 3,13, alışveriş imkânları 3,13, can ve mal güvenliği 3,01 ortalamaları ile katılımcıların bu deneyimleri yeterli buldukları görülmektedir. Son olarak yerel festivallerin imkânı 2,92 ve trafik altyapısı 2,41 ortalama ile bu kriterlerin yetersiz olarak değerlendirildiği söylenilebilir.

Yerel Halkın Kültürel Bir Destinasyon Olarak Kaleiçi’ne Yönelik Algılarına İliş̧kin Araştırma Bulguları

Yerel halkın ifadelere katılım durumlanı incelendiğinde "Kültürel ve tarihi yapıların korunması 
ve iyileştirilmesi Kaleiçi'nin turistik geleceği açısından olumlu olacaktır" ifadesine \%83 oranında katıldıkları, "Kaleiçi tam anlamıyla kültürel bir şehir destinasyonudur" ifadesine \%73,6 oranında katıldıkları, "Kaleiçi, Türkiye'deki diğer kültürel yapılarla rekabet edecek potansiyele sahiptir" ifadesine $\% 72,3$ oranında katıldıkları, "Kaleiçi'ne ait kültür ile ilgili hoş deneyimlerim oldu" ifadesine \%68,3 oranında katıldıkları, "Kültürel ve tarihi kaynaklar Kaleiçi'ni tercih etmemdeki en önemli nedenlerdendir" ifadesine $\% 60$ oranında katıldıkları görülmektedir. Ayrıca son olarak "Kültürel bir destinasyon olarak Kaleiçi'nin tanıtımı etkili bir şekilde yapılmaktadır” ifadesine \%51,3 oranında katılmadıkları sonucu görülmektedir.

Tablo 6. Yerel Halkın Kültürel Bir Destinasyon Olarak Kaleiçi Algılamalarına Yönelik Ortalamaları

\begin{tabular}{|c|c|c|}
\hline & Aritmetik Ortalama & Standart Sapma \\
\hline $\begin{array}{l}\text { Kültürel ve tarihi yapıların korunması ve } \\
\text { iyileştirilmesi Kaleiçi'nin turistik geleceği açısından } \\
\text { olumlu olacaktır. }\end{array}$ & 4,14 & 1,2707 \\
\hline $\begin{array}{l}\text { Kaleiçi tam anlamıyla kültürel bir şehir } \\
\text { destinasyonudur. }\end{array}$ & 3,75 & 1,3031 \\
\hline $\begin{array}{l}\text { Kaleiçi, Türkiye'deki diğer kültürel yapılarla rekabet } \\
\text { edecek potansiyele sahiptir. }\end{array}$ & 3,74 & 1,3304 \\
\hline Kaleiçi'ne ait kültür ile ilgili hoş deneyimlerim oldu. & 3,63 & 1,2341 \\
\hline $\begin{array}{l}\text { Kültürel ve tarihi kaynaklar Kaleiçi’ni tercih } \\
\text { etmemdeki en önemli nedenlerdendir. }\end{array}$ & 3,38 & 1,3983 \\
\hline $\begin{array}{l}\text { Kaleiçi, genel olarak kültürel amaçlı ihtiyaç ve } \\
\text { beklentilerimi karşıladı. }\end{array}$ & 3,36 & 1,2502 \\
\hline $\begin{array}{l}\text { Kaleiçi'ndeki kültürel ve tarihi yapıların çok } \\
\text { bakımsı ve ihmal edilmiş durumda olduğunu } \\
\text { düşünüyorum. }\end{array}$ & 2,95 & 1,4472 \\
\hline Kaleiçi seyahatim tamamen kültürel amaçlı idi. & 2,69 & 1,3103 \\
\hline $\begin{array}{l}\text { Kültürel bir destinasyon olarak Kaleiçi’nin tanıtımı } \\
\text { etkili bir şekilde yapılmaktadır. }\end{array}$ & 2,39 & 1,3949 \\
\hline
\end{tabular}

Yerel halkın kültürel bir destinasyon olarak Kaleiçi'ni algılamalarına yönelik ortalamalar Tablo 6'da gösterilmiştir. Tabloya göre “Kültürel ve tarihi yapıların korunması ve iyileştirilmesi Kaleiçi'nin turistik geleceği açısından olumlu olacaktır” ifadesine 4,14 gibi büyük bir oranla katıldıkları görülmektedir. "Kaleiçi'ndeki kültürel ve tarihi yapıların çok bakımsız ve ihmal edilmiş durumda olduğunu düşünüyorum" ifadesine 2,95, "Kaleiçi seyahatim tamamen kültürel amaçlı idi" ifadesine 2,69 ve "Kültürel bir destinasyon olarak Kaleiçi'nin tanıtımı etkili bir şekilde yapılmaktadır" ifadesine 2,39 oranında katılmadıklarını belirtmişlerdir.

\section{Yerel Halkın Kaleiçi’nde Bulunan Kültürel Yapılar İle İlgili Bilgi Düzeyi Bulguları}

Katılımcılara, Kaleiçi’nde bulunan 50 tane kültürel yapılarının bilinirliğine ilişkin bulgular Tablo 7'de gösterilecektir. "Bilmiyorum, biliyorum ama gezmedim, biliyorum ve gezdim" cevabını en çok tekrar eden 5 yapı değerlendirmeye alınmıştır.

Tablo 7. Kaleiçi’nin Kültürel Yapılarına Yönelik Bilgi Düzeyi Tablosu

\begin{tabular}{|l|l|l|}
\hline \multicolumn{1}{|c|}{} & Bilmiyorum \\
\cline { 2 - 3 } & F & \% \\
\hline Nigâr Hatun Türbesi & 180 & 60 \\
\hline Ahi Kızı Mescidi & 170 & 56,7 \\
\hline Ahi Kızı Türbesi & 167 & 55,7 \\
\hline
\end{tabular}




\begin{tabular}{|l|l|l|}
\hline Zincirkıran Mehmet Bey Türbesi & 155 & 51,7 \\
\hline Nazır Hamamı & 155 & 51,7 \\
\hline & Biliyorum Ama Gezmedim & \\
\hline Cumhuriyet (Balbey) Hamamı & 117 & 39 \\
\hline $\begin{array}{l}\text { Yivli Minare (Mevlevihane) } \\
\text { Hamamı }\end{array}$ & 113 & 37,7 \\
\hline Antalya Lisesi İdari Binaları & 105 & 35 \\
\hline Tekeli Mehmet Paşa Camii & 101 & 33,7 \\
\hline Atatürk Evi Ve Müzesi & 100 & 33,3 \\
\hline & Biliyorum ve Gezdim & \\
\hline Saat Kulesi & 248 & 82,7 \\
\hline Karaalioğlu Parkı & 242 & 80,7 \\
\hline Kale Kapısı & 238 & 79,3 \\
\hline Yat Limanı & 235 & 78,3 \\
\hline Hadrianus Kapısı (Üç Kapılar) & 223 & 74,3 \\
\hline
\end{tabular}

Kaleiçi'nin kültürel yapılarına yönelik bilgi düzeyi tablosuna göre katılımcıların \%60'1 Nigâr Hatun Türbesi'ni, \%56,7'si Ahi Kızı Mescidi'ni, \%55,7'si Ahi Kızı Türbesi'ni, \%51,7'si Zincirkıran Mehmet Bey Türbesi'ni, \%51,7'si Nazır Hamamı'nı, bilmiyorum olarak belirtmişlerdir. Katılımcıların \%39'u Cumhuriyet Hamamı'nı, \%37,7'si Yivli Minare Hamamını, \%35'i Antalya Lisesi İdari Binaları'nı, \%33,7'si Tekeli Mehmet Paşa Camii'sini, \%33,3’ü Atatürk Evi ve Müzesini, biliyorum ama gezmedim olarak belirtmişlerdir. Katılımcıların \%82,7'si Saat Kulesi'ni, \%80,7'si Karaalioğlu Parkı'nı, \%79,3'ü Kale Kapısı'nı, \%78,3'ü Yat Limanı'nı, \%74,3'ü Hadrianus Kapısı'n1, biliyorum ve gezdim olarak belirtmişlerdir. Sonuç olarak en az bilinen yapının Nigâr Hatun türbesi ve en çok bilinen yapının ise Saat Kulesi olduğu görülmektedir.

\section{Sonuç ve Öneriler}

Türkiye, tarihî ve coğrafi yapısıyla zengin bir ülkedir. Bu durum ülkenin kültürel çeşitliliğinin zenginleşmesine neden olmaktadır. Akdeniz Bölgesi’nde yer alan Antalya da tarihî yapıları ve kültürel çeşitliliği ile zengin bir konumdadır. Antalya'nın en eski destinasyonlarından biri olan Kaleiçi Bölgesi'nin de geçmişi antikçağa kadar uzanmaktadır. Kaleiçi, geçmişini günümüze kadar ulaştıran bir bölge olması sebebiyle kültür turizmi potansiyelini de giderek yukarı çıkarmaktadır. Bu potansiyeller arasında Hadrianus Kapısı, Yivli Minare, Hıdırlık Kulesi gibi tarihî yapıların yanında tarihî hamamlar, idari binalar, dinî yapılar, müzeler ve rekreasyon alanları gibi önemli yapılar ve alanlar yer almaktadır. Bu yapılar içerisinde Roma, Doğu Roma, Selçuklu ve Rum yapıları da bulunmaktadır. Bu sebeple farklı kültürlerin ve farklı yaşantıların tarihî izlerini görmek mümkündür.

Kaleiçi’nin mevcut potansiyelinin ne kadar kullanıldığı da düşündürücüdür. Fakat günümüzde Büyükşehir Belediyesi, Muratpaşa Belediyesi ve Akdeniz Üniversitesi gibi kurumların düzenlediği festivaller, yaptığı yenileme çalışmaları sayesinde bu mevcut potansiyelin daha da artacağı görülmektedir.

Trafik alt yapısı ve yerel festivallerin varlığının, veriler sonucu düşük olduğu görülmektedir. $\mathrm{Bu}$ durum da bazı sorunları ortaya koymaktadır. Trafik sorununun giderilmesi için belediyeler gerekli önlemleri almalı ve belirli düzenlemeler yapmalıdır. Yerel festivaller, belediyeler ve İl Turizm Müdürlükleri tarafindan desteklenmelidir. 
Katılımcıların çoğu kültürel ve tarihî yapıların korunmasının ve iyileştirilmesinin Kaleiçi'nin turistik geleceği açısından olumlu olacağını düşünmektedir. Ayrıca katılımcılar kültürel bir destinasyon olarak Kaleiçi'nin tanıtımının etkili bir şekilde yapılmadığını düşünmektedirler. Bu sonuç reklam ve tanıtım açısından Kaleiçi'nin eksik kaldığını göstermektedir. Yapılacak reklam ve pazarlama çalışmaları ile Kaleiçi'nin tanıtımı yapılabilir ve birçok kişiye ulaşması sağlanabilir.

Kaleiçi’nin katılımcılara neyi çağrıştırdığı sorulduğunda tarih, kültür ve eğlence kavramları ön plana çıkmıştır. Bu sonuç tarihin ve kültürün Kaleiçi için çok önemli bir etken olduğunu göstermektedir. Fakat "turizm" kavramının düşük bir oranla belirtilmesi de turizm açısından Kaleiçi'nin olumsuz bir görüntü vermekte olduğunu göstermektedir. Turistin Kaleiçi'ne yönelmesi ile hem turistik bir canlılık meydana gelebilir hem de bölge esnafı bu durumdan olumlu etkilenebilir.

Analiz sonuçlarında belirtilen önerilere ek olarak; kültürel, tarihî ve doğal güzellikleriyle olumlu bir görüş alan Kaleiçi'nin turizm açısından aynı olumlu görüşü bulduğunu söylemek mümkün değildir. Gerek güncel turizm sorunları sebebiyle gerekse turisti otelden ayırmayan her şey dâhil sistemi sebebiyle birçok etken gibi Kaleiçi de bu durumdan zarar görmüştür. Kaleiçi'nin daha iyi ve doğru öğretilmesi, bölgenin tanınırlığını ve yerel halkın bilgi seviyesini artıracaktır. Bu sebeple bir rehberlik birimi kurulabilir ve Kaleiçi'ni gezmek isteyenler rehberler sayesinde daha bilinçli bir şekilde bölgeyi gezebilir.

"Yerel Halkın Kaleiçi Kültür Turizmine İlişkin Algıları" adlı çalışmada elde edilen sonuçlar ve sunulan önerilerin, "Kaleiçi” ve "Kültür Turizmi” ile ilgili yapılacak akademik çalışmalara ve projelere yol göstereceği ve bu kapsamda alana değer katacağı öngörülmektedir.

\section{Yazarın Notu}

"Yerel Halkın Kaleiçi Kültür Turizmi Potansiyeline İlişkin Algıları" adlı çalışmamın hazırlık sürecinde sahip olduğu bilgi birikimi ile bana yol gösteren ve desteğini esirgemeyen saygideğer hocam Yrd. Doç. Dr. Nurşah Şengül'e ve Yrd. Doç. Dr. Ece Ömüriş'e sonsuz teşekkürlerimi sunarım. 


\section{KAYNAKÇA}

Ahipaşaoğlu S. \& Çeltek E. (2006). Sürdürülebilir Kırsal Turizm. Ankara 2006.

Avcı Ü. (2015b). “Konut Mimarisinde Çakıl Mozaik Sanatı: Antalya Kaleiçi Örneği”. Art Sanat 4 (2015) 111-135.

Bandeoğlu Z. (2015). “Türkiye'de Kültür Turizmi Potansiyeli Üzerine Bir Değerlendirme”. Kahramanmaraş Sütçü İmam Üniversitesi İktisadi ve İdari Bilimler Fakültesi Dergisi 5/2 (2015) 155-168.

Bramwell B. \& Bernard L. (2000). Tourism Collaboration and Partnerships: Politics, Practice And Sustainability. 2000.

Çakır N. (1999). Eski Kentsel Yerleşim Birimlerimizin Kültür Turizmimizdeki Yeri ve Önemi Safranbolu Örneği. Yayımlanmamış Yüksek Lisans Tezi. Balıkesir Üniversitesi, Sosyal Bilimler Enstitüsü. Balıkesir 1999.

Çulha O. (2008). "Kültür Turizmi Kapsamında Destekleyici Turistik Ürün Olarak Deve Güreşi Festivalleri Üzerine Bir Alan Çalışması”. Journal of Yaşar University 3/12 (2008) 1827-1852.

Delice A. (2010). "Nicel Araştırmalarda Örneklem Sorunu". Cal 13/2 (2010) 151-170.

Doğaner S. (2013). Türkiye Kültür Turizmi. 2013.

Dönmez C. \& Yeşilbursa C. C. (2014). "Kültürel Miras Eğitiminin Öğrencilerin Somut Kültürel Mirasa Yönelik Tutumlarına Etkisi”. İlkögretim Online 13/2 (2014) 425-442.

Emekli G. (2003). “Kültür Mirasının Kültürel Turizm Yaklaşımıla Değerlendirilmesi 2”. Coğrafi Çevre Koruma ve Turizm Sempozyumu (2003) 16-18.

Erdoğan N. (2003). Çevre ve (Eko)Turizm. Ankara 2003.

Fuchs M., Gasser R. \& Weiermair K. (1995). "Cultural Tourism as a Segment of Growth: The Role and İmportance of Events and Event Management”. In Archeology \& Managament of Cultural Tourism (1995) 21-34.

Genim S. (2002). “Kültür Turizmi”. T.C. Turizm Bakanllğg II. Turizm Şuarası Bildirileri 12-14 Nisan 2002 (2002) 205-210. Ankara.

Göğebakan Y. (2014). “Hüsamettin Koçan'ın Çalışmalarındaki Kültür Varlığı ve Kültür Mirasına Ait Unsurlar”. Inönü Üniversitesi Sanat ve Tasartm Dergisi 4/10 (2014) 47-57.

Gökalp Z. (1976). Türkçülüğün Esasları. İstanbul 1976.

Gönel F. D. (2002). "Globalleşen Dünyada (Nasıl Bir) Sürdürülebilir Kalkınma”. Birikim Dergisi 158 (2002) $72-80$

Günay R. (2007) "Kültür Mirasını Korumada Çeşitli Yaklaşımlar”. Colloquium Anatolicum VI (2007) 1-25.

Güvenç B. (2011). Insan ve Kültür. İstanbul 2011.

Himmetoğlu B. (1996). "Sürdürülebilir Turizmi Gerçekleştirme Yolları, Sürdürülebilir Turizm; Turizm Planlamasına Ekolojik Yaklaşım”. 19. Dünya Şehircilik Günü Kolokyumu (1996).

Jayaram J., Kannan V. \& Tan K. C. (2004). "Influence of Initiators on Supply Chain Value Creation”. International Journal of Production Research 42/10 (2004) 38-51.

Kabaağaç S. \& Alova E. (1995). Latince Türkçe Sözlük. İstanbul 1995.

Kepenek E., Gençel Z. \& Berna G. Ü. Ç. (2015). “Antalya Tarihi Kent Merkezi ve Yakın Çevresindeki Mekansal Değişimin Günümüz Kent Formuna Etkilerinin Değerlendirilmesi”. SDÜ Mühendislik Bilimleri ve Tasartm Dergisi 3/2 (2015) 77-84.

Khalilova K. (2008). "Kültür Turizmi Bakımından Azerbaycan Şirvan Bölgesinin Arz Potansiyelinin Değerlendirilmesi”. DEÜ Sosyal Bilimleri Enstitüsü (2008).

Kozak M. \& Martin D. (2012). "Tourism Life Cycle and Sustainability Analysis: Profit-Focused Strategies Fotr Mature Destinations”. Tourism Management 33/1 (2012) 188-194.

Kozak M. (2015). Bilimsel Araştırma: Tasarım, Yazım ve Yayım Teknikleri. Ankara 2015.

Kuter N. \& Ünal E. H. (2009). "Sürdürülebilirlik Kapsamında Ekoturizmin Çevresel, Ekonomik ve Sosyo-Kültürel Etkileri”. Kastamonu Üniversitesi Orman Fakültesi Dergisi 9/2 (2009) 146-156.

Küçükaslan N. (2007). Özel İlgi Turizmi. Bursa 2007.

Kültür ve Turizm Bakanlığı. (2013). Gelenekten Geleceğe: Türkiye'de Somut Olmayan Kültürel Miras. 
Ankara 2013.

Lembet U. Z. (2012). “Kültür Dil ve Tüketim ve Reklam İlişkisi”. Eds. M. Babaoğul, A. Şener \& B. Buğday, Tüketici Yazıları (2012) 44-65. Ankara.

McKercher B. \& Du Cros H. (2002). Cultural Tourism- The Partnership Between Tourism and Cultural Heritage Managament. Routledge 2002.

Meriç C. (1986). Kültürden Irfana. İstanbul 1986.

Özdemir R. (1992). “Osmanlı Döneminde Antalya’nın Fiziki ve Demografik Yapısı (1800-1867)”. Tarih Incelemeleri Dergisi 7/1 (1992) 133-166.

Pedersen A. (2002). "Managing Tourism at World Heritage Sites. A Practical Manual for World Heritage Site Managers”. ICOMOS (2002).

Pfoor C. (2001). "Concepts of Sustainable Development, Sustainable Tourism and Ecotourism: Definitions, Principles, and Linkages”. Scandinavian Journal Of Hospitality And Tourism 1/1 (2001) 68-71.

Sagona A. \& Zimansky P. (2015). Arkeolojik Veriler Işı̆̆ında Türkiye’nin En Eski Kültürleri. M.Ö. 1.000.000 - 550. İstanbul 2015.

Schweitzer C. (1999). “Cultural Tourism: The Hot Ticket to Cool Meetings”. Association Management 5/8 (1999) 121-130.

Uygur S. M. \& Baykan E. (2007). "Kültür Turizmi ve Turizmin Kültürel Varlıklar Üzerindeki Etkileri”. Ticaret ve Turizm Eğitim Fakültesi Dergisi 2 (2007) 30-49.

Üsküdar Ş. (2012). Eskişehir'in Kültür Turizmi Potansiyeli ve Yerli Turistlerin Buna İlişkin Algıları Üzerine Bir Araştırma. Yayımlanmamış Yüksek Lisans Tezi. Anadolu Üniversitesi, Sosyal Bilimler Enstitüsü. Eskişehir 2012.

\section{İnternet Kaynakları}

Kültür Varlıkları ve Müzeler Genel Müdürlüğü. <http://www.kulturvarliklari.gov.tr/TR,44423/dunyamiras-listesi.html>.

TÜIKK. <www.tüik.gov.tr/PreIstatistikTablo.do?istab_id=1590>.

UNESCO. <http://www.unesco.org.tr/?page=11:125:5:turkce>. 